\title{
Fetal Cerebellar Tissue Associated with a Primitive Neuro-epithelial Tumor in an Ovarian Teratoma
}

\author{
PAUL J. BOOR AND WILLIAM C. SCHOENE
}

SUMMARY: This is a single case report of an ovarian teratoma. It is a unique case of a primitive neuroepithelial tumor with many similarities to a medulloblastoma arising in an ovarian teratoma, and the second report of fetal cerebellum occurring in a teratoma of the ovary.

RESUMÉ: II s'agit du premier cas rapporté d'une tumeur primitive neuro-épithéliale ressemblant au médulloblastome et se développant dans un tératome ovarien, et le second cas rapporté de cervelet fétal survenant dans un tératome de l'ovaire.
From the Department of Pathology, Division of Neuropathology, Peter Bent Brigham Hospital, and the Department of Pathology, Harvard Medical School.

Reprint requests to Dr. William C. Schoene, Department of Pathology (Neuropathology), Peter Bent Brigham Hospital, 721 Huntington Avenue, Boston, Massachusetts U.S.A. 02115.

\section{INTRODUCTION}

There have been four reports of cerebellar tissue in an ovarian teratoma (Askanazy, 1907; Bettinger, 1941; MacSween, 1968; Willis, 1939). In one of these (MacSween, 1968), three well-developed fetal cerebellar folia with a definite external granular layer were found.

The following case is the second report of fetal cerebellum in an ovarian teratoma. Spongioblastic differentiation is seen in the primitive neuro-epithelial component of this teratoma, which is thought by the authors to be similar to a medulloblastoma.

\section{CASE REPORT \\ Clinical Description}

A 23-year-old black woman was admitted to the Peter Bent Brigham Hospital because of diffuse abdominal pain of four months' duration accompanied by anorexia, increasing abdominal girth and recent weight loss of 60 pounds. The pertinent physical findings were ascites, diffuse abdominal tenderness without rebound pain and distant bowel sounds. Ultrasound studies of the abdomen disclosed a huge abdominal mass which was both cystic and solid. At laparotomy a massive cys. tic structure at the site of the right

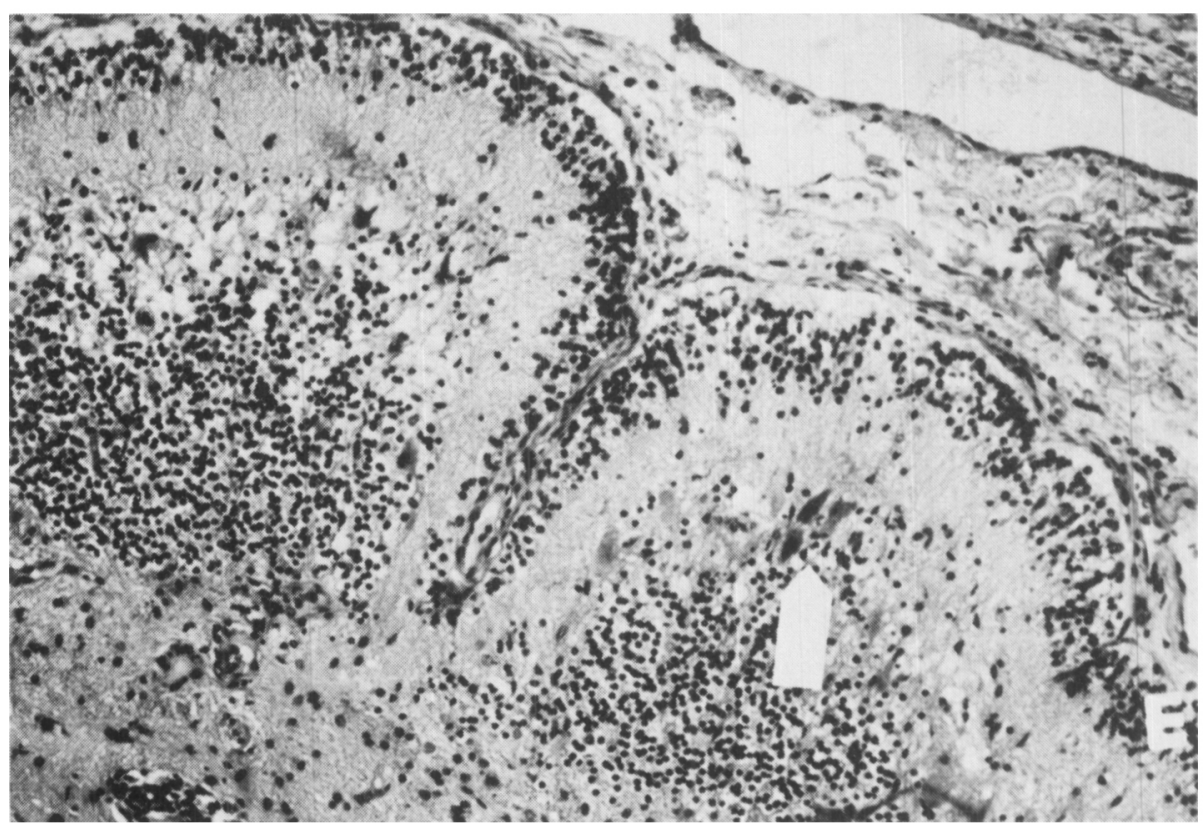

Figure $1-$ Two folia of fetal cerebellar tissue within an ovarian teratoma. Note definite external granular cell layer (E) and Purkinje cells (arrow). (x100) 
ovary was removed. The patient's post-operative course over the past five months has been uneventful.

\section{PATHOLOGY}

\section{Gross Description}

The right ovary was replaced by a large cystic and focally solid mass which weighed $5,810 \mathrm{gms}$. and measured $23 \times 19 \times 17 \mathrm{~cm}$. An $8 \mathrm{~cm}$. length of fallopian tube and a portion of the omentum were attached to it by fibrous adhesions. Approximately $60 \%$ of the ovarian mass was made up of multiloculated cysts. They contained yellow-to-orange serous fluid and had glistening smooth walls except for an occasional maroon polypoid projection. The solid portion of the tumor was variegated, with soft tan and purple regions and firm white nodules. Focal grittiness and tufts of hair were noted but structures such as teeth or fingers were not seen.

\section{Microscopy}

The largest component of the ovarian tumor mass consisted of mature elements including squamous, ciliated, pseudo-stratified and mucin-producing columnar epithelium along with hair, cartilage, bone, smooth muscle and fat. Various epithelia and glial tissue lined the cysts. Immature mesenchymal tissue was seen in some fields.

Tissues of neuro-epithelial origin, varying in maturity, were found predominantly in the solid portions of the teratoma.

Well-formed fetal cerebellar folia characterized by a definite external granular cell layer, molecular layer, Purkinje neurons and an internal granular cell layer were identified (Figs. 1 and 2). In some fields, the fetal cerebellar tissue was not so well-organized and contained poorly-defined molecular and granular cell layers mịxed with Purkinje cells. Adjacent to the fetal cerebellar tissue, and merging with it, was a mass of glial tissue as well as a highly cellular region composed of round cells with prominent basophilic stippled nuclei and a scant amount of cytoplasm (Fig. 2). These primitive cells were often arranged in strands or islands (Fig 3)

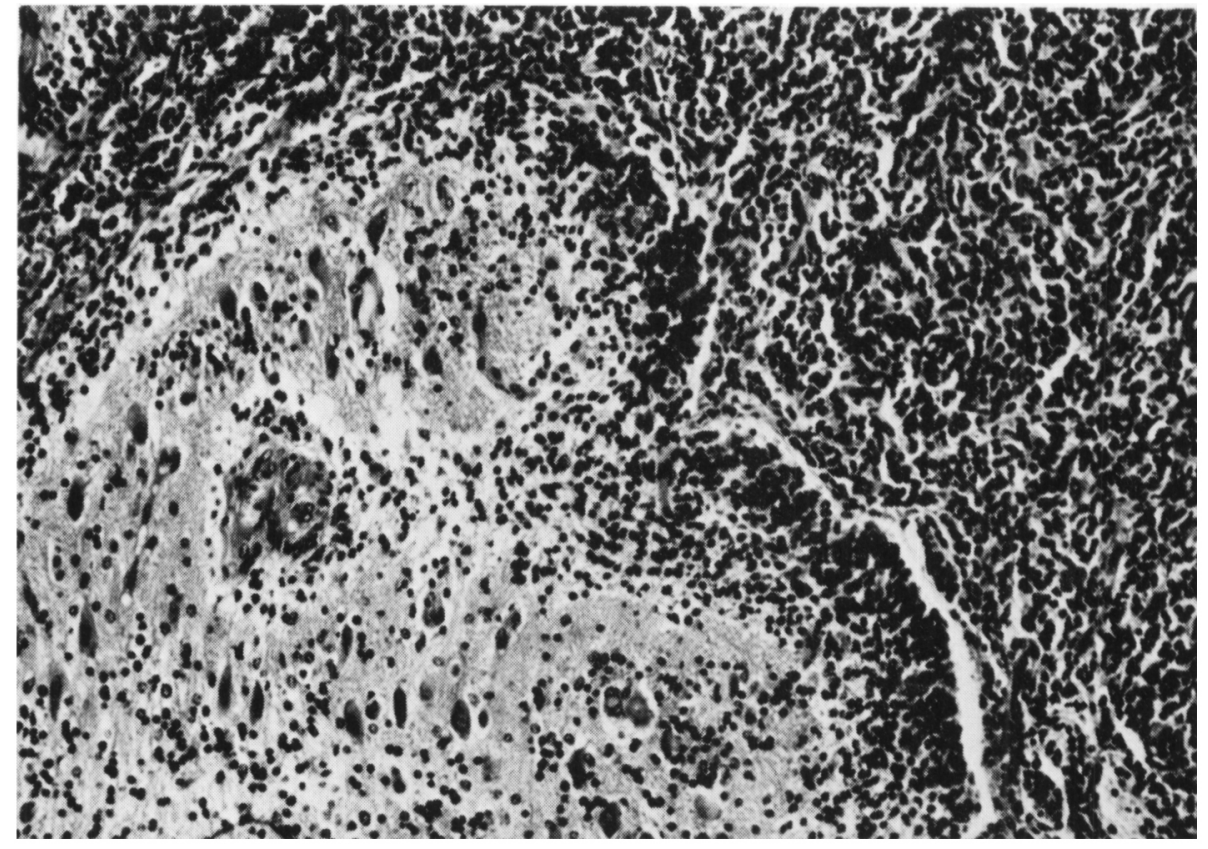

Figure 2-Extremely cellular neuro-epithelial tumor (upper right) juxtaposed to cerebellar tissue (lower left). (x100)

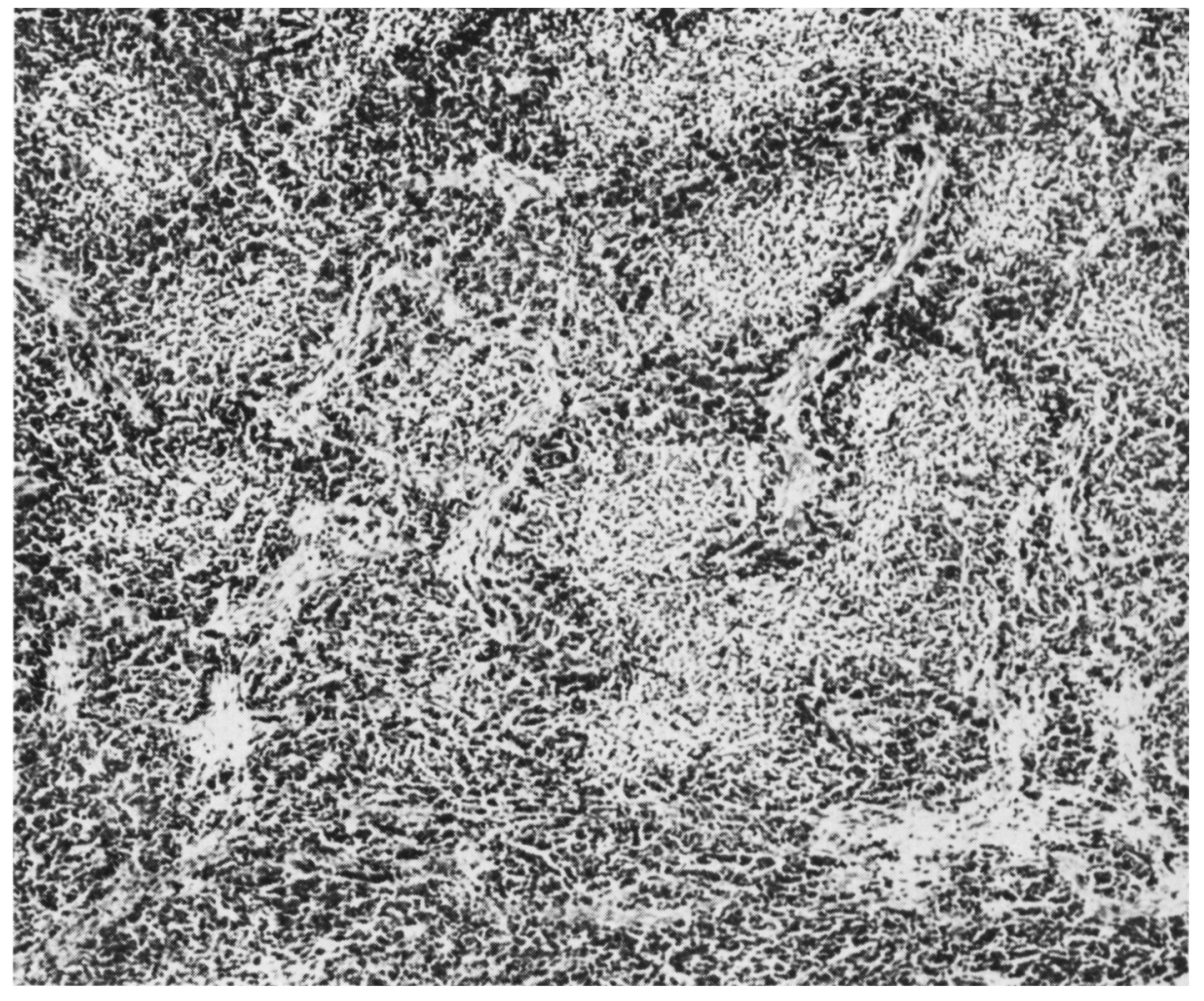

Figure 3-Primitive neuro-epithelial tumor cells arranged in strands and islands. $(x 40)$ 


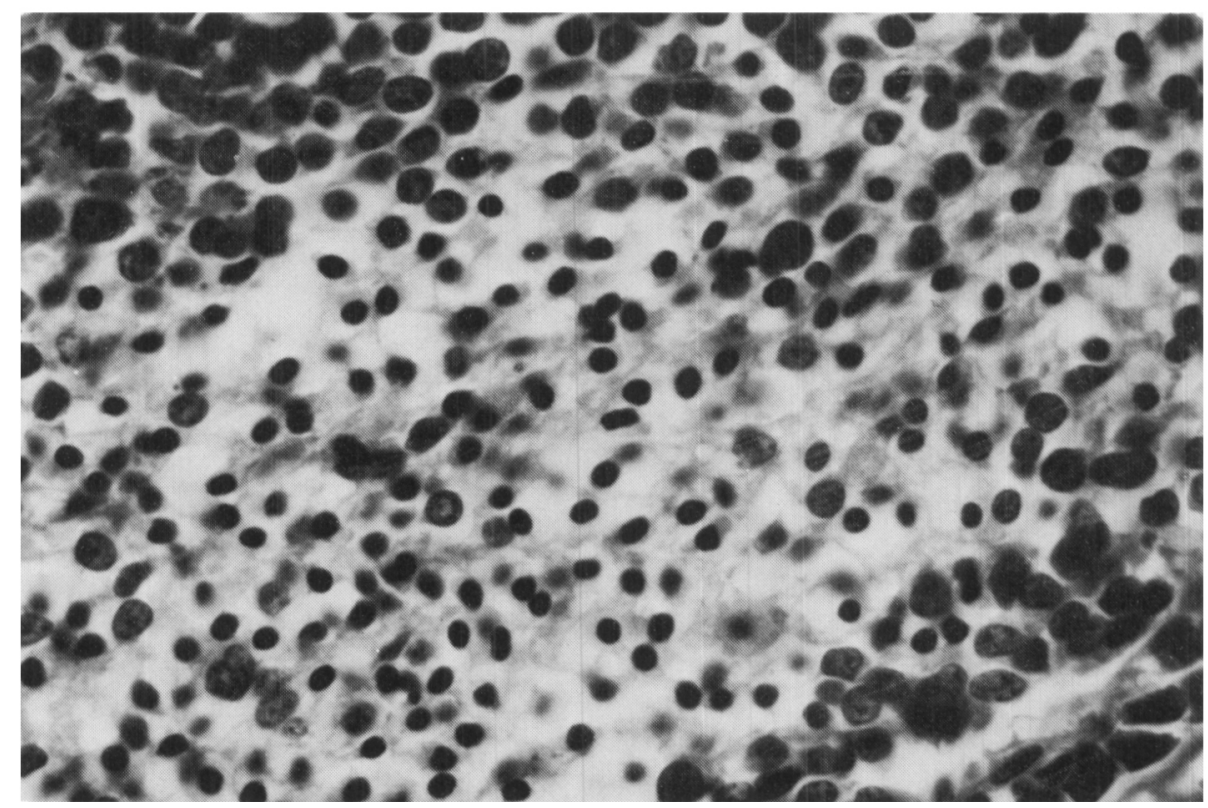

Figure 4-Neuro-epithelial tumor cells with a scant amount of cytoplasm and a fibrillary background. (x250)

and appeared to merge with primitive glial cells with more definite cytoplasmic processes associated with a fibrillary background (Fig. 4). Occasional rosettes were seen.

Special stains, including PTAH, Reticulin and Masson preparations were negative in the primitive neuro-epithelial regions except for a rare $\mathrm{PTAH}$ positive fiber.

\section{CONCLUSION}

The variety of adult and embryonal tissue in this tumor is consistent with an embryonal teratoma (Scully, 1970). This teratoma is unusual, however, because it contains a large proportion of mature and immature neuro-epithelial elements and has contributed to our understanding of neuro-epithelial differentiation in a tumor originating in a site distant from the nervous system.

Medulloblastoma has been characterized as arising from primitive neuro-epithelial cells (Bailey \& Cushing, 1925; Kadin et al., 1970; Russel \& Rubinstein, 1971) which have the potential to differentiate along a glial and/or neuronal line. This entity is said to be restricted to the cerebellum (Russel \& Rubinstein, 1971).

In the ovarian teratoma described above, the primitive neuro-epithelial component appeared to show transition toward recognizable neoplastic glial tissue, i.e. spongioblastic differentiation, in association with well-developed fetal cerebellar tissue. These morphological findings bear a striking resemblance to a medulloblastoma and suggest that a tumor histologically indistinguishable from a medulloblastoma can upon rare occasions occur in a site distant from the posterior fossa.

The co-existence of the fetal cerebellar tissue with this medulloblastoma-like tumor might give some indirect support to the external granular cell origin of medulloblastoma hypothesized by several authors. (Kadin et al., 1970; Russel \& Rubinstein, 1971; Stevenson \& Schlin, 1934).

In summary, this is a unique case of a primitive neuro-epithelial tumor with many similarities to a medulloblastoma arising in an ovarian teratoma and the second report of fetal cerebellum occurring in a teratoma of the ovary.

\section{REFERENCES}

ASKANAZY, M. (1907). "Die Teratome nach ihrem Bau, ihrem Verlauf, ihrer Genese und im Vergleich zum experimentallen Teratoid," Verh. Dtsch. Path. Ges. $11,39$.

BAILEY, P., CUSHING, H. (1925). "Medulloblastoma Cerebelli, a common type of mid-cerebellar glioma of childhood," Arch. Neurol. and Psychiat. 14, 192.

BETTINGER, H. F. (1941). " Two ovarian teratomata, one containing cerebellar, the other, cerebral cortex," J. Path. Bact. 53, 284.

KADIN, M. E., RUBINSTEIN, L. J. and NELSON, J. S. (1970). "Neonatal cerebellar medulloblastoma originating from the fetal external granular layer," J. Neuropath. Exptl. Neurol. 29, 583.

MacSWEEN, R. N. M. (1968). “Foetal cerebellar tissue in an ovarian teratoma," $J$. Path. Bact. 96, 513.

RUSSEL, D. S. and RUBINSTEIN, L. J. (1971). Pathology of Tumors of the Nervous System (3rd ed.), Edward Amold (Publishers) Ltd., London, p. 182.

SCULLY, R. E. (1970). "Recent progress in ovarian cancer," Human Path. 1, 73.

STEVENSON, L., and SCHLIN, F. (1934). "Nature and origin of some tumors of the cerebellum," Arch. Neurol. and Psychiat. $31,93$.

WILLIS, R. A. (1939). "An ovarian teratoma containing cerebellar tissue," J. Path. Bact. $49,571$. 